\title{
REVIEW
}

\section{JORDI SALES I CODERCH. ESCRITS SOBRE FILOSOFIA CATALANA. ESTUDI INTRODUCTORI I EDICIÓ A CURA DE JOSEP MONSERRAT, EPÍLEG DE XAVIER SERRA. CABRERA DE MAR: GALERADA, 2019.}

\author{
Joan Cuscó i Clarasó (iD \\ (Universitat de Barcelona) \\ joancusco@ub.edu
}

\begin{abstract}
Volume: Jordi Sales i Coderch. Escrits sobre filosofia catalana. Estudi Introductori i Edició a cura de Josep Montserrat. Epíleg de Xavier Serra. Cabrera de Mar: Edicions Galerada, 2019, 208 pp., ISBN-10: 849678687, ISBN-13: 978-8496786875.

Acknowledgements: Project IEC PRO2018-S05. Models del dret i la filosofia política catalanes: semàntica de les doctrines juridicopolitiques del pactisme en les seves diferents fases [Models of Catalan political philosophyand law: Semantics of pact-model driven political and legal doctrines at their different stages].

Disclosure statement: No potential conflict of interest was reported by the authors.

License: This work is under Attribution-NonCommercial-NoDerivs 3.0 Unported (CC BY-NC-ND 3.0) http://creativecommons.org/licenses/by-nc-nd/3.0/

Suggested citation: Cuscó, J. (2019-2020). "Ressenya de Jordi Sales Coderch. Escrits sobre filosofia catalana. Estudi introductori , edició a cura de Josep Monserrat, epíleg de Xavier Serra. Cabrera de Mar, 2018, 205 p.”, Journal of Catalan Intellectual History 12: pp. 109-111 DOI: 10.2478/jocih-2019-0007
\end{abstract}

(C)2021, Journal of Catalan Intellectual History

In recent years, in reviewing their intellectual biography, neurologists Oliver Sacks, first, and Joaquim $\mathrm{M}^{\mathrm{a}}$ Fuster, later, explain and underscore the importance of the links they created from a very young age with their own intellectual environments; or rather, with the discipline and topics that over the years shaped their work. Joaquim $\mathrm{M}^{\mathrm{a}}$ Fuster-despite the poor philosophical atmosphere of the city of Barcelona during the Franco regime-can rediscover the spur of the works of Joan Lluís Vives and Ramon y Cajal. Progressively, in addition to his familiarisation with the work of these authors, he traces their way of embracing the concerns and challenges of those who have preceded him in the task of working on human consciousness around the world. He feels connected to it and recognises its merits because, as he says: "Memory is, in fact, essential for learning, retaining experiences, imagination, remembrance, reasoning, emotion, education, the arts and social life with other human beings".

The book collects the works on the history of Catalan philosophy by Professor Jordi Sales and in doing so, it shows three relevant facts: first, the importance of recognising those who have preceded us; second, the reason why the study of the history of philosophy is essential for any Catalan philosopher and third, why Catalan philosophy is the one that, as in the case of Fuster, 
allows him to place himself in a space and a time. There is, in this sense, a double goal: to know the philosophy of one's own culture in the most rigorous possible way and to incorporate these authors into one's intellectual background. Furthermore, as the work of Jordi Sales is the resultof an academic philosopher, it has a clear pedagogical vocation. His work La captivitat inadvertida (2013), which has been published by the same publishing house Galerada, shares a similar tone and also follows a similar intellectual vein.

The collection of texts contains a prologue written by Josep Monserrat (also in charge of the edition) and an epilogue by Xavier Serra, which highlight Jordi Sales' constant dedication to the research of philosophy in Catalonia and to the role that, according to him, it must play in Catalan society. Besides elaborating historiographic studies, Jordi Sales is interested in active learning, intending to reflect on philosophy, within contemporary Catalonia, and with the support of the inherited philosophical baggage. An approach which he practised during his teaching years at the University of Barcelona and as president of the Societat Catalana de Filosofia.

Jordi Sales has always been aware of the lack of continuity within the Catalan philosophy of the twentieth century, due to political and institutional reasons, and he has said that for this reason it must be done with the utmost thoroughness and from the grass-roots up, with a broad vision but without aiming to pass it off as what it has not been nor as what it could not and did not want to be. The important thing, we are reminded in the book, is the construction of a firm philosophical thought within Catalan culture, and this cannot be accompanied by merely erudite or pompously hagiographic history of philosophy. Besides, as is explained in the first chapter, it is necessary to develop the possibility of an institutional framework in which both history and philosophical thought can be based and have continuity within contemporary Catalan culture, and be done with seriousness and independence. He suggests associations, universities, periodicals, conferences... It is a matter of being aware that the past, the present and the future are inseparable and that in any philosophical tradition, continuity, dialogue, research and reflection are necessary. We cannot think that we start from scratch and that projection and dialogue with the outside world and historical knowledge are two necessary opposing paths, especially because, although many times it is thought that Catalan philosophy has been isolated within European culture, this is not true and it needs explaining.

The authors that Sales analyses are diverse: Pere Coromines (1870-1939), Jaume Serra Hunter (1878-1943), Carles Cardó (1884-1943), Francesc Mirabent (1888-1952), Joaquim Xirau (1895-1946) and Eduard Nicol (1907-1990). Most of them were linked to the University of Barcelona and made a coherent work which had an influence on various areas of Catalan culture in the twentieth century. Sales reads the work of these authors directly and also studies what they have meant for Catalan academic philosophy. He scrutinises its projection outside Catalonia, its successes and in search of those contributions that can serve us in today's philosophical works. Sales' gaze is lucid and ironic. Aware of the political situation established by a dictatorship that banned the Catalan language and caused the exile of many of these authors is a fact that we cannot overlook and that hasdistorted its reception and projection.

Sales offers a plural, diverse and enriching perspective of the Catalan philosophical thought of the twentieth century, which also serves as an introduction to some of its main authors and some of its main problems. He allows every author to talk with their own voice and reviews 
some of their most recent studies on them and their work. Sales deploys analytical and critical scrutiny at the same time.

These are some of the merits of the book that collects disseminated works and yet has a strong internal consistency, showing a way of doing things appropriate to the object of study and to its purposes. As Jordi Sales writes in p. 81: "Eliminating the predecessors themselves in each step of history is to condemn each generation from heroism of adventure. A resource that, however commendable it may be, and it is very, it cannot fail to condemn us to great intellectual poverty." 